\title{
SALIVA AND SERUM MALONDIALDEHYDE LEVELS IN APPARENTLY HEALTHY INDIVIDUALS IN KURDISTAN REGION / IRAQ
}

\author{
NAZDAR M. OMER, BDS, MSc * \\ QASIM H. ABDULLAH, MBChB, MSc, PhD ** \\ HAZHMAT A. ALI, BVM\&S, MSc***
}

\section{Submitted 1/11/2017; accepted 31/12/2017}

\begin{abstract}
Background: Saliva is a fluid secreted by the salivary glands and it is divided in to serous and mucus components. Despite its physiological roles in lubricating the oral cavity and digestion, it also acts as a simple diagnostic tool reflecting body's systemic diseases. The aim of the present study is to determine malondialdehyde (MDA) levels in saliva and serum of apparently healthy individuals and to find if there is an association between dental caries, periodontal disease and salivary MDA.

Subject and Methods: This cross sectional study involved sixty fourparticipants who were medical students attending Duhok College of Medicine. Clinical information and all relevant data were obtained according to a questionnaire. Both salivary and serum MDA levels were measured manually in unstimulated saliva and sera of participants using Thiobarbuturic acid method.
\end{abstract}

Results: Malondialdehyde is measurable in saliva of apparently healthy individuals and was significantly lower than serum MDA level $(\mathrm{p}<0.001)$. There was a statistically highly significant positive correlation between both salivary and serum MDA levels $(p=0.0007)$. Moreover, both Salivary and serum MDA levels were significantly positively correlated with weight and BMI $(\mathrm{p}=0.03, \mathrm{p}=0.03$ and $\mathrm{p}=0.04$ and 0.05$)$ respectively. There were no significant correlations between salivary MDA with dental caries index (dmft score) and periodontal disease index.

Conclusions: Based on the current results, salivary MDA is significantly positively correlated with serum MDA, weight and BMI. No significant association of salivary MDA with dental caries and periodontal disease were observed.

Duhok Med J 2017; 11 (2): 11-18

Keywords: Malondialdehyde, Periodontal disease and saliva.

\begin{tabular}{|c|c|}
\hline $\begin{array}{l}\text { aliva is a fluid secreted by salivary } \\
\text { glands and about } 600 \mathrm{ml} \text { is secreted } \\
\text { daily }{ }^{1} \text {. Both serous and mucus components } \\
\text { of saliva contain a variety of substances } \\
\text { like minerals, enzymes, electrolytes and } \\
\text { even immunoglobulins }{ }^{2} \text {. Despite its } \\
\text { physiological roles in lubricating oral } \\
\text { cavity and digestion, saliva represents a }\end{array}$ & $\begin{array}{l}\text { part of the immune system containing } \\
\text { immunoglobulin (mainly IgA) and non- } \\
\text { immunological factors (lysozyme, } \\
\text { lactoferrin,histatins and salivary } \\
\text { peroxidase systems) protecting the oral } \\
\text { cavity from different types of antigens. } \\
\text { Studies emphasized the role of saliva as a } \\
\text { simple diagnostic tool reflecting body's }\end{array}$ \\
\hline
\end{tabular}

\footnotetext{
* Assistant Lecturer, Department of Medical Physiology and Pharmacology, College of Medicine, University of Duhok, Kurdistan Region, Iraq.

** Professor, Department of Medical Physiology and Pharmacology, College of Medicine, University of Duhok, Kurdistan Region, Iraq.

***Lecturer, Department of Medical Physiology and Pharmacology, College of Medicine, University of Duhok, Kurdistan Region, Iraq.

Correspondence author to: Qasim H. Abdullah, qasim.hasso@uod.ac, Mobil +9647504506580. 
systemic diseases ${ }^{3}$.

However,Lipid peroxidation has a free radical chain reaction which causes degeneration of cell membranes.

Lipid peroxides are disintegrated quickly and form reactive carbon compounds. Among these, MDA is an important reactive carbon compound which is used commonly as an indicator of lipid peroxidation ${ }^{4}$. Malondialdehyde (MDA) which is the end byproduct of lipid peroxidation has been implicated as a marker for oxidative stress in a variety of pathological conditions including periodontal diseases ${ }^{5}$.

Previous studies indicated that increased MDA levels are closely associated with the severity of periodontal disease. In addition, detection of salivary MDA level may provide additional advantages in elucidating the pathogenesis of periodontal disease $^{6,7}$. The aim of the present study is to investigate the possibility of detection and measurement of malondialdehyde in saliva of apparently healthy individuals and to find out if there is any correlation between salivary, serum MDA, BMI and some oral health indices.

\section{SUBJECTS AND METHODS}

After receiving an approval letter from medical research ethics committee, this cross sectional study was performed at Department of Medical Physiology from September - December 2017. The study involved sixty four (25 males and 39 females) apparently healthy participants who weresecond stage medical college students at University of Duhok. There ages were ranged between 20-21 years. All participants gave their informed consent. At the beginning, oral examination was done for each participant by a professional dentist and both periodontal index ${ }^{8}$ and dmft (decayed, missed, filled teeth)score ${ }^{9}$ were estimated according to referenced criteria. This followed by collecting unstimulated saliva and venous blood samples for measurement of MDA levels. Both salivary and serum MDA levels were measured manually using thiobarbuturic acid method ${ }^{10}$.

Other relevant parameters such as weight, height and BMI in addition to other necessary information were obtained.Statistical analysis was done using SPSS software version 18. Results were expressed as mean \pm standard error. $\mathrm{t}$-Test used to estimate the statistical significance between two variables. One way ANOVA was used to calculate the statistical differences between several variables. The $p$ value $<0.05$ was considered statistically significant.

\section{RESULTS}

Demographic characteristics, mean salivary and serum MDA levels of study subjects are shown in Table $\mathbf{1 .}$

\begin{tabular}{|c|c|c|}
\hline \multicolumn{3}{|c|}{$\begin{array}{c}\text { Table1: Demographic parameters, mean } \\
\text { salivary and serum MDA levels of the study } \\
\text { group. }\end{array}$} \\
\hline Parameters & Mean \pm SE & $P$ value \\
\hline $\begin{array}{l}\text { Height }(\mathrm{cm}) \\
\text { Weight }(\mathrm{kg}) \\
\text { Body Mass Index (BMI, } \\
\left.\mathrm{kg} / \mathrm{m}^{2}\right) \text {. }\end{array}$ & $\begin{array}{c}166 \pm 0.02 \\
58.62 \pm 2.33 \\
21.2 \pm 0.59\end{array}$ & \\
\hline $\begin{array}{l}\text { Number and percentage } \\
\text { of male participants. }\end{array}$ & $25(39 \%)$ & \\
\hline $\begin{array}{l}\text { Number and percentage } \\
\text { of female participants. }\end{array}$ & $39(61 \%)$ & \\
\hline $\begin{array}{l}\text { Salivary MDA } \\
(\mathrm{ng} / \mathrm{ml})\end{array}$ & & $<0.001$ \\
\hline $\begin{array}{l}\text { vs } \\
\text { Serum MDA } \\
(\mathbf{n g} / \mathrm{ml})\end{array}$ & $1.31 \pm 0.16$ & \\
\hline
\end{tabular}


Mean salivary MDA level was significantly lower than serum MDA level ( $p<0.001$. According to gender, there were no statistically significant differences in both salivary and serum MDA levels ( $p=$ 0.17 and 0.34 ) respectively, (Table2).

Table 2: Comparison between mean salivary and serum MDA according to gender.

\begin{tabular}{|c|c|c|c|}
\hline Parameters & $\begin{array}{c}\text { GroupI } \\
(\text { male } \\
\text { n=25) } \\
\text { Mean } \pm \\
\text { SE }\end{array}$ & $\begin{array}{c}\text { Group II } \\
\text { (females } \\
\text { n=39) } \\
\text { Mean } \pm \\
\text { SE }\end{array}$ & $\begin{array}{c}p \\
\text { value }\end{array}$ \\
\hline $\begin{array}{l}\text { Salivary } \\
\text { Malondialdehyde } \\
\text { (MDA), ng/ml }\end{array}$ & $\begin{array}{c}1.04+ \\
0.79\end{array}$ & $0.8+0.44$ & 0.17 \\
\hline $\begin{array}{l}\text { Serum } \\
\text { Malondialdehyde } \\
\text { (MDA), ng/ml }\end{array}$ & $\begin{array}{c}1.41+ \\
0.68\end{array}$ & $\begin{array}{c}1.21+ \\
0.65\end{array}$ & 0.34 \\
\hline
\end{tabular}

Based on dmft score and periodontal index, mean salivary and serum MDA levels didn't show statistically significant differences, (Tables 3).

Table 3: Comparison between mean salivary and serum MDA according to dmft score and periodontal index.

\begin{tabular}{|c|c|c|}
\hline $\begin{array}{l}\text { dmft Score/ } \\
\text { Periodontal } \\
\text { Index }\end{array}$ & $\begin{array}{l}\text { Salivary } \\
\text { Malondialdehyde } \\
\text { (MDA), ng/ml }\end{array}$ & $\begin{array}{l}\text { Serum } \\
\text { Malondialdehyde } \\
\text { (MDA), ng/ml }\end{array}$ \\
\hline $\begin{array}{c}\text { dmft Score } \\
(0-6) \\
\text { N }=45 \\
\text { dmft Score }\end{array}$ & $0.89 \pm 0.18$ & $1.29 \pm 0.19$ \\
\hline $\begin{array}{l}(7-12) \\
N=19\end{array}$ & $0.86 \pm 0.24$ & $1.36 \pm 0.35$ \\
\hline$p$ value & 0.45 & 0.42 \\
\hline $\begin{array}{l}\text { Periodontal } \\
\text { index 0-0.2 } \\
\quad N=30\end{array}$ & $0.92 \pm 0.22$ & $1.36 \pm 0.26$ \\
\hline $\begin{array}{c}\text { Periodontal } \\
\text { index 0.3- } \\
0.9 \\
N=24\end{array}$ & $0.91 \pm 0.27$ & $1.28 \pm 0.29$ \\
\hline $\begin{array}{l}\text { Periodontal } \\
\text { index 1-1.9 } \\
\quad N=8\end{array}$ & $0.79 \pm 0.52$ & $1.23 \pm 0.4$ \\
\hline $\begin{array}{c}\text { Periodontal } \\
\text { index } 2- \\
\text { more } \\
\mathrm{N}=2 \\
p \text { value }\end{array}$ & $0.51 \pm 0.45$ & $1.33 \pm 0.69$ \\
\hline
\end{tabular}

Table 4, shows the spearman's correlation coefficient between both serum and salivary MDA with other parameters.

Table 4: Spearman's correlation coefficient between MDA and other parameters

\begin{tabular}{lcc}
\hline \multicolumn{1}{c}{ Parameters } & $r$ value & $\begin{array}{c}p \\
\text { value }\end{array}$ \\
\hline Salivary MDA - Serum MDA & $\mathbf{0 . 4 1}$ & $\mathbf{0 . 0 0 0 7}$ \\
Salivary MDA - height & $\mathbf{0 . 1 3 8}$ & $\mathbf{0 . 2}$ \\
Salivary MDA - weight & $\mathbf{0 . 2 6 5}$ & $\mathbf{0 . 0 3}$ \\
Salivary MDA - BMI & $\mathbf{0 . 2 6 8}$ & $\mathbf{0 . 0 3}$ \\
Salivary MDA - dmft & $-\mathbf{0 . 0 8}$ & $\mathbf{0 . 4}$ \\
Salivary MDA - perio & $-\mathbf{0 . 1 6}$ & $\mathbf{0 . 1}$ \\
Serum MDA - height & 0.1 & $\mathbf{0 . 4}$ \\
Serum MDA - weight & $\mathbf{0 . 2 4 1}$ & $\mathbf{0 . 0 4 8}$ \\
Serum MDA - BMI & $\mathbf{0 . 2 3 1}$ & $\mathbf{0 . 0 5}$ \\
Serum MDA - dmft & $\mathbf{0 . 0 9}$ & $\mathbf{0 . 4 5}$ \\
Serum MDA - perio & $\mathbf{- 0 . 0 0 7}$ & $\mathbf{0 . 9}$ \\
\hline
\end{tabular}

There was a statistically highly significant positive correlation between salivary and serum MDA levels $p=0.0007$, (figure - 1). Salivary MDA was significantly positively correlated with both weight and BMI $(p=0.03)$. Serum MDA as well displayed significant positive correlations with weight and BMI ( $p=0.04$ and 0.05) respectively. There were no significant correlations between salivary MDA with dmft score and periodontal index.

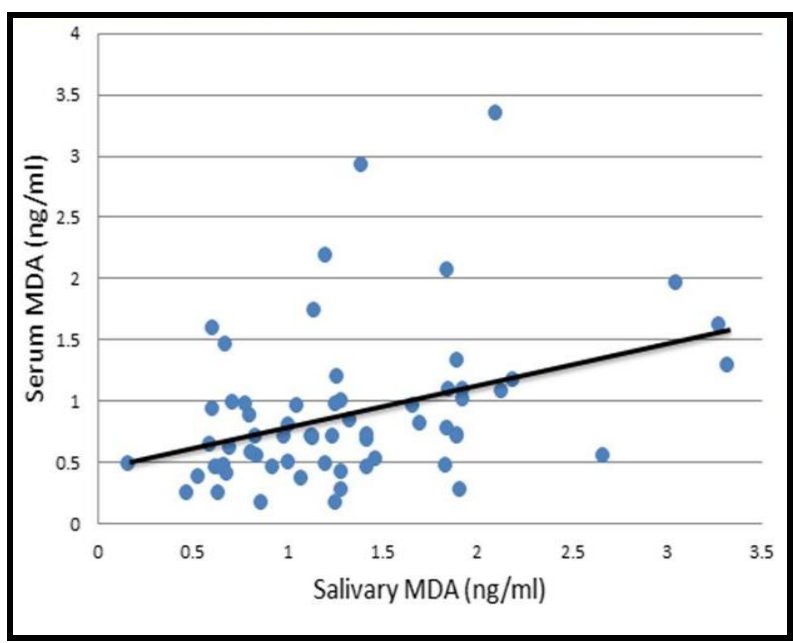

Figure 1: Correlation coefficient between salivary and serum MDA. 


\section{SALIVA AND SERUM MALONDIALDEHYDE LEVELS IN APPARENTLY}

\section{DISCUSSION}

This cross - sectional study was conducted on a group of apparently healthy subjects of same age group and of both gender. Unstimulated salivary sample were used to detect and measure MDA, because unstimulated saliva contains higher concentrations of screening and diagnostic biomarkers ${ }^{11}$.In the current study, MDA was detected and measured spectrophotometrically in saliva and serum, salivary MDA was about $31.3 \%$ lower than serum MDA (0.9 vs $1.31 \mathrm{ng} / \mathrm{ml}$, $\mathrm{p}<0.001)$. Comparison of salivary and serum MDA levels between males and females were statistically not significant; similar finding were observed by Motamayel et $\mathrm{al}^{12}$; However, Block et $\mathrm{al}^{13}$ found significantly higher lipid peroxidation among women but they were unable to explain this difference and hypothesized that to the higher percentage of body fat in women. In contrary Tothova et $\mathrm{al}^{14}$ found Thiobarbituric acid reacting substances (TBARS) concentration in saliva sample of boys was significantly higher than girls.

No significant different in salivary and serum MDA levels were detected between those with low dmft score (0-6) and high dmft score (7-12) and also no significant correlations were observed between $\mathrm{dmft}$ score with salivary and serum MDA levels. Rai et al ${ }^{15}$ reported no statistical different in salivary MDA level between caries-free subject and those with dental caries, moreover, Tothova et al ${ }^{14}$ found that caries index as a marker of dental status is not a significant determinant of salivary MDA level. The possible reason behind such no difference may be the subjects involved in this study are well educated person and probably they routinely and regularly brush teeth and have good oral hygiene.

Previous studies showed significantly higher level of MDA is periodontitis ${ }^{12,15,16}$ with higher lipid peroxidation in patients with severe but not moderate periodontitis, however in the current study no significant difference in salivary and serum MDA levels were observed according to periodontal index, with no significant correlation, most of the subject involved in study have no or mild periodontitis, periodontal index was between 0-0.9 in 54 subjects out of total 64 .

There was highly significant positive correlation between salivary and serum MDA levels $(p=0.0007)$. Smriti et $\mathrm{al}^{17}$ found strong and significant positive correlation between serum and salivary MDA in both controls and diabetics. This indicates that salivary MDA in diabetic patients may result from a state of systemic dyslipidemia and serum composition is reflected in the saliva composition.

Present study showed significant positive correlations between MDA (serum and salivary) with weight and body mass index. Similar findings were observed by Atabay et al ${ }^{18}$ indicating that increases in serum and salivary MDA levels associated with increased weight and BMI, regardless of periodontal status, are reflective of increases in oxidative stress as a result of obesity. Obesity may be described as a state in which systemic, low-grade inflammatory stimulus can produce oxidative stress ${ }^{18}$. In contrast to our findings Blok et al ${ }^{13}$ found that body mass index is not associated with MDA. 
The limitations of this study were small sample size, subjects were of same age group and all were medical college students. Therefore, further studies are indicated with larger sample size, different age groups and from different sectors and occupations in the community.

In conclusion; according to the current findings, salivary MDA is significantly positively correlated with serum MDA, weight and BMI. No significant association of salivary MDA with dental caries and periodontal disease were observed.

\section{REFERENCES}

1- Khoubnasabjafari M, Ansarin K, Jouyban A. Reliability of malondialdehyde as a biomarker of oxidative stress in psychological disorders. Bioimpacts. 2015; 5:123-7.

2- Khademi H, Khozeimeh F, Tavangar A, Amini S, Ghalayani P. The Serum and salivary level of malondialdehyde, vitamins $\mathrm{A}, \mathrm{E}$, and $\mathrm{C}$ in patient with recurrent aphthous stomatitis. Adv Biomed Res. 2014; 6;3:246.

3- Maryam K, Khalil A and Abolghasem J. Salivary malondialdehyde as an oxidative stress biomarker in oral and systemic diseases. J of Dent Res., Dent Clinics Dent. Prospect. 2016; 10(2):7174.

4- Tappel AL. Lipid peroxidation damage to cell components. Clin Pathol Fed Proc. 1973;32:1870-1874.

5- Yagi K. Lipid peroxides and altered radicals in clinical medicine. Adv Exp Med Biol. 1994; 366:1-15.

6- Nakhjavani M, Esteghamati A, Nowroozi S, Asgarani F, Rashidi A, Khalilzadeh O. Type 2 diabetes mellitus duration: an independent predictor of serum malondialdehyde levels. Singapore Med J. 2010; 51:582585.

7- Khoubnasabjafari M, Ansarin K, Jouyban A. Comments concerning "Comparison of airway and systemic malondialdehyde levels for assessment of oxidative stress in cystic fibrosis". Lung. 2015; 193:867-8.

8- Russel AL. Epidemiology of periodontal disease. Int Dent J .1967; 17: 282-29.

9- Shahrabi M, Nikfarjam jm, Alikhani A, Akhoundin N, Ashtiani M, Seraj B. A Comparison of salivary calcium, phosphate and alkaline phosphatase in children with severe, moderate caries and caries free in Tehran's kindergartens. J Indian Soc Pedod prevent Dent. 2008; 46: 121-129.

10-Grune T, Siems W, Esterbauer H. Comparison of different assays for MDA using thiobarbitoric acid. Forescius J Anal Chem. 1992; 343:135.

11- Rathnayake N, Gieselmann DR, Heikkinen AM, Tervahartiala T, Sorsa T. Salivary Diagnostics-Point-of-care diagnostics of MMP-8 in dentistry and medicine. Journal of Diagnostics. 2017; 7(1): 7.

12-Ahmad - Motamayel FA, Goodarzi MT, Jamshidi Z, Kebriaei R. Evaluation of Salivary and Serum Antioxidant and Oxidative Stress Statuses in Patients with Chronic Periodontitis: A case- control Study. Frontiers in physiology. 2017; 8: 1-6.

13-Block G, Dietrich M, Norkus EP, Marrow JD, Hudes M, Caan B, Packer L. Factors Associated with Oxidative 


\section{SALIVA AND SERUM MALONDIALDEHYDE LEVELS IN APPARENTLY}

Stress in Human Populations. oxidative stress in oral diseases.

American Journal of Epidemiology. Frontiers in cellular and infection 2002; 15(3): 274-285.

14- Tóthová L, CelecovaV and Celec P. Salivary markers of oxidative stress and their relation to periodontal and dental status in children. Disease Markers. 2013; 34: 9-15.

15-Rai B, Kharb S, Jain R, Anand SC. Salivary Lipid Peroxidation Product Malondialdehyde in various Dental Diseases. World Journal of Medical Sciences. 2006; 1(2): 100-101.

16- Tóthová L, Kamodyová N, Červenka $\mathrm{T}$, Celec P.Salivary markers of microbiology. 2015; 5: 1-23.

17-Smriti K, Pai KM, Ravindranath V, Pentapati KC. Role of salivary malondialdehyde in assessment of oxidative stress among diabetics. Journal of BIOLOGY and Craniofacial Research. 2016; 6: 4-44.

18-Atabay VE, Lutfiğlu M, Avci B, Sakallioglu EE, Ayadogdu A. Obesity and oxidative stress in patients with different periodontal status: a casecontrol study. Journal of Periodontal Research. 2017; 52(1):51-60. 


\section{ثُختة}

\section{مهلسهنكهندنا مالون داينهلديهاد دخويينيّ وسيوميّ دا ل دهف كهسييّن ساخلهم ل مهريّما كودستانيّ/ عيراق}

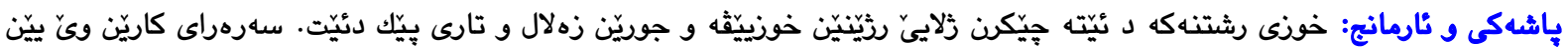

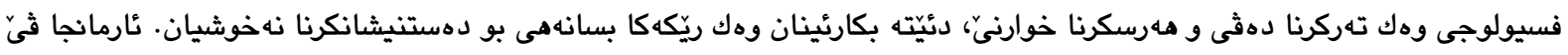

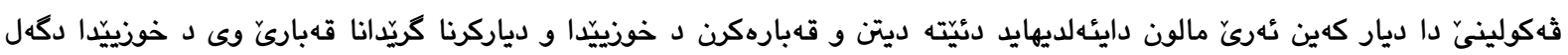

قهباريّ وى د خوينيّا.

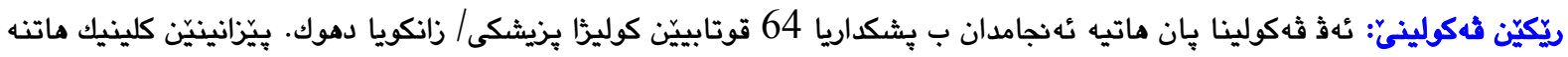
توماركرن. قهباريّ مالون دايئهلديهايد هاته بشكنينكرن د خوزيييّ ود خوينيّدا بريكا ترشيّ تايوباربيجيورئيك.

ئهنجام: مالون دايئهلديهايد هاته ديتن و قهبارمكرن دخوزيا كهسيّن ساخلهمدا و ريّزَديهكا بهرجاث كيّمتر بوو ز

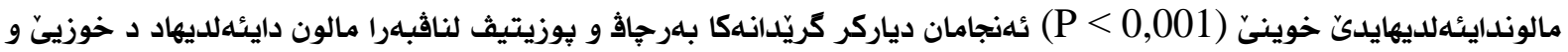

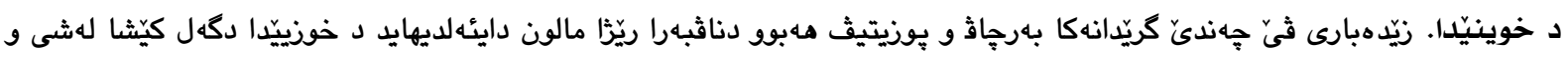

$$
\text { BMI(P = 0,03 , P = 0,03 , P = 0,04 and P = 0,03) }
$$

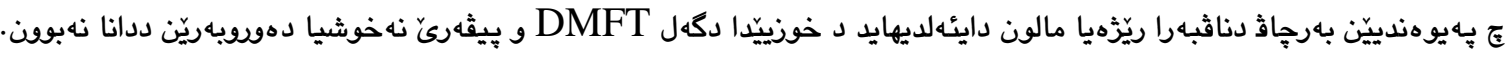

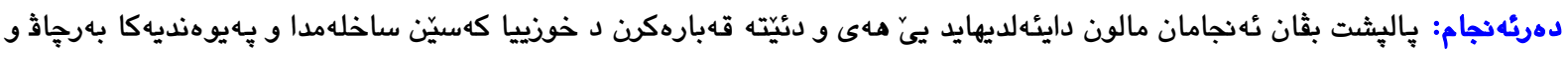

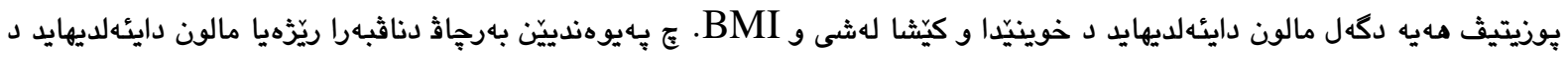

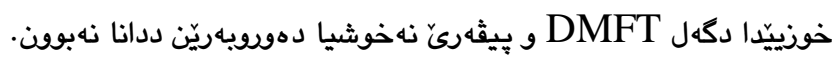




\section{الخلاصة}

قياس المالون دايألديهايد فى اللعاب والمصل لادى الاشخاص الطبيعيين في اقليم كردستان/العرلق

الخلفية والأهداف: اللعاب هو سائل يفرز من قبل الغدد اللعابية و يتكون من السوائل المصلية والمخاطية. بالاظافة الى الوظيفة الفسلجية للعاب المتمثل بترطيب التجويف الفمي و الهضم, يستخدم كوسيلة تشخيص سهلة بنعكس امراض مهن الجسم. الهدف من البحث هو بيان مدى امكانية قياس المالون دايألديهايد في عينات لعاب الاشخاص الاصحماء و و هل

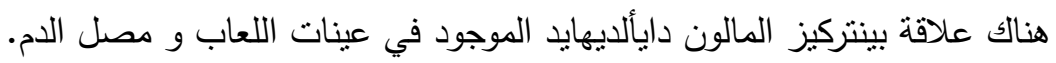

طرق البحث: تضمنت هذة الدراسة العرضية64 مشاركا اصحاء الذين كانوا طلاب كلية الطب في جامعة دهوك. بعد

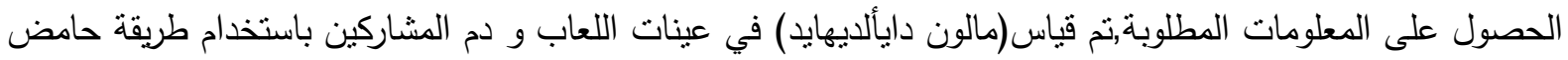
ثايوباربوجوريك.

النتائج: تمكن ايجاد و قياس المالون دايألديهايد في عينات لعاب المشاركين الاصحاء وكان التركيز اقل و معنوي

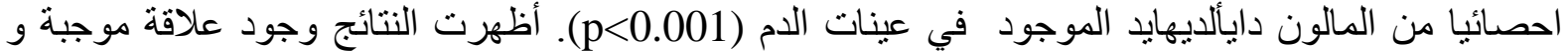

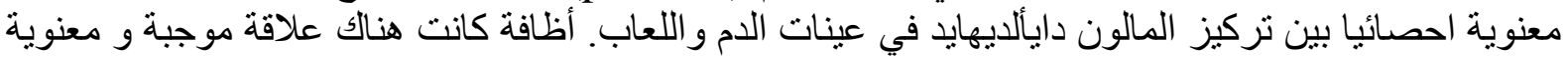

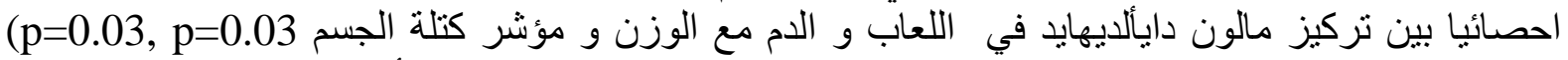
and P = 0.04 and 0.05) DMFT ومؤشر مرض ما حول السن.

الاستنتاجات: استتادا الى هذه النتائج نوجد علاقة موجبة ومعنوية بين المالون دايألديهايد في عينات لعاب و بين

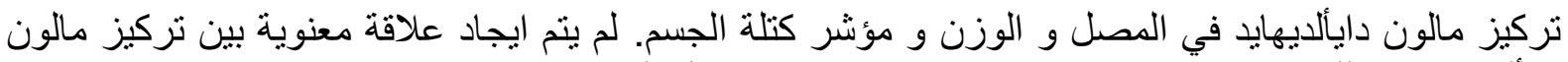
دائلديهايد في اللعاب و مقياس DMFT ومؤشر مرض مرض مونس ما حول السن. 